\title{
A moment frozen in time: evidence of a late fifth-century massacre at Sandby borg
}

Clara Alfsdotter ${ }^{1}$, Ludvig Papmehl-Dufay ${ }^{2, *} \&$ Helena Victor $^{2}$

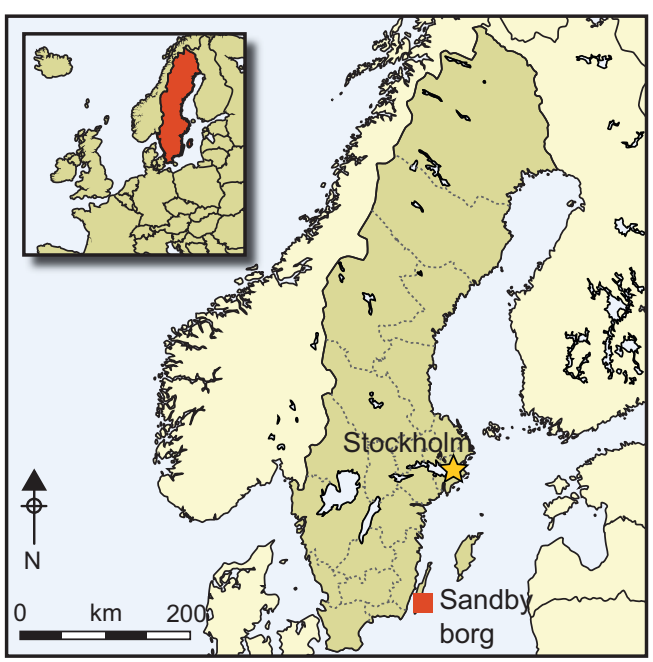

The European Migration Period (c. AD 400-550) was characterised by political, social and economic instability. Recent excavations at Sandby borg ringfort on the island of Öland in Sweden have revealed indisputable evidence of a massacre which occurred at that time. Osteological, contextual and artefactual evidence strongly suggest that the fort was abandoned immediately following the attack and was left undisturbed throughout antiquity. Sandby borg offers a unique snapshot of domestic life and abrupt death in the Scandinavian Migration Period, and provides evidence highly relevant to studies of ancient conflict, and on social and military aspects of Iron Age and Migration Period societies.

Keywords: Sweden, Sandby borg, Migration Period, violence, fortification, massacre

\section{Introduction}

Southern Scandinavia was never part of the Roman Empire, but Roman influence is evident in the archaeological record of present-day Denmark and southern Sweden. The middle Iron Age (c. AD 200-600) in this region is characterised by hierarchical societies in which religious, social and economic power was confined to the hands of a ruling elite, with social networks reaching far into the Roman Empire to the south (Näsman 1984a; Lund Hansen 1987; Jørgensen 2003; Fischer 2005). Long-distance travel was a means to gather wealth and obtain status in a hierarchical and unstable political power structure, not least by winning control of metal imports by the means of networks established through such

\footnotetext{
1 Department of Archaeology, Bohusläns Museum, Museigatan 1, 45119 Udevalla, Sweden

2 Department of Museum Archaeology, Kalmar County Museum, Box 104, Kalmar S-39121, Sweden

* Author for correspondence (Email: lpd@kalmarlansmuseum.se)
}

(C) Antiquity Publications Ltd, 2018. This is an Open Access article, distributed under the terms of the Creative Commons Attribution licence (http://creativecommons.org/licenses/by/4.0/), which permits unrestricted reuse, distribution and reproduction in any medium, provided the original work is properly cited. 
Table 1. Basic chronology of the Swedish Iron Age (the period of the Sandby borg massacre is indicated).

\begin{tabular}{ll}
\hline Date & Period \\
\hline $500-1$ BC & Pre-Roman Iron Age \\
AD 1-400 & Roman Iron Age \\
AD 400-550 & Migration Period \\
AD 550-750 & Vendel Period \\
AD 750-1050 & Viking Age \\
\hline
\end{tabular}

contacts (Herschend 1991; Jørgensen 2003, 2011; Fischer 2005; Hedeager 2011; Andrén 2014).

The Migration Period was a turbulent time in both Scandinavia and the rest of Europe (Table 1). The decline of the Western Roman Empire, the invasion of the Huns, war, famine and shifting alliances within the Barbaricum (Germanic populations beyond the Roman Border in the northern parts of Europe) all had impacts on societies (Lund Hansen 1987; Fischer 2005; Heather 2006; Fischer \& Victor 2011; Hedeager 2011). A social and economic crisis can be identified in various areas of Scandinavia during this time, as indicated by an abrupt decline in settlement activities, with numerous examples of farms being deserted or even destroyed during this time (Stenberger 1933; Näsman 1988).

Excavations at Sandby borg ringfort, on the island of Öland in south-east Sweden, have revealed unique traces of a Migration Period (c. 400-550 AD) massacre. Our conclusions are based on the discovery of human remains from at least 26 individuals, several of whom display lethal traumatic injuries, the skeletal remains of animals abandoned following the assault and artefacts recovered from the site.

Öland is located off the south-east Swedish coast in the Baltic Sea (Figure 1). Here, the archaeological record from the Roman Iron Age and Migration Period is exceptionally rich, including more than 1000 visible stone house foundations, innumerable accompanying stone fences, thousands of cemeteries and graves, and at least 15 ringforts (Stenberger 1933; Fallgren 2006, 2008). To this should be added numerous prestigious and exclusive items, including bronze statuettes, glass beakers and gold coins of Roman origin. At least 360 solidi are known from the island - more than from any other region in Scandinavia (Fagerlie 1967; Herschend 1980; Fischer et al. 2011). The main influx of gold coins seems to have occurred in the early to mid fifth century; this decreased dramatically after AD 476 (Fischer et al. 2011).

\section{The Sandby borg ringfort}

The ringfort of Sandby borg is located adjacent to the shoreline on south-east Öland. Today, the structure consists of an eroded oval stone wall enclosing an area of approximately $5000 \mathrm{~m}^{2}$. Three gates are visible as shallow depressions in the wall. The walls would originally have been approximately $4-5 \mathrm{~m}$ high. Aerial photographs and geophysical surveys of the ringfort interior revealed buried stone structures, interpreted as stone house walls (Borg et al. 1976; Viberg 2012; Viberg et al. 2014). The layout is similar to that of several (C) Antiquity Publications Ltd, 2018 


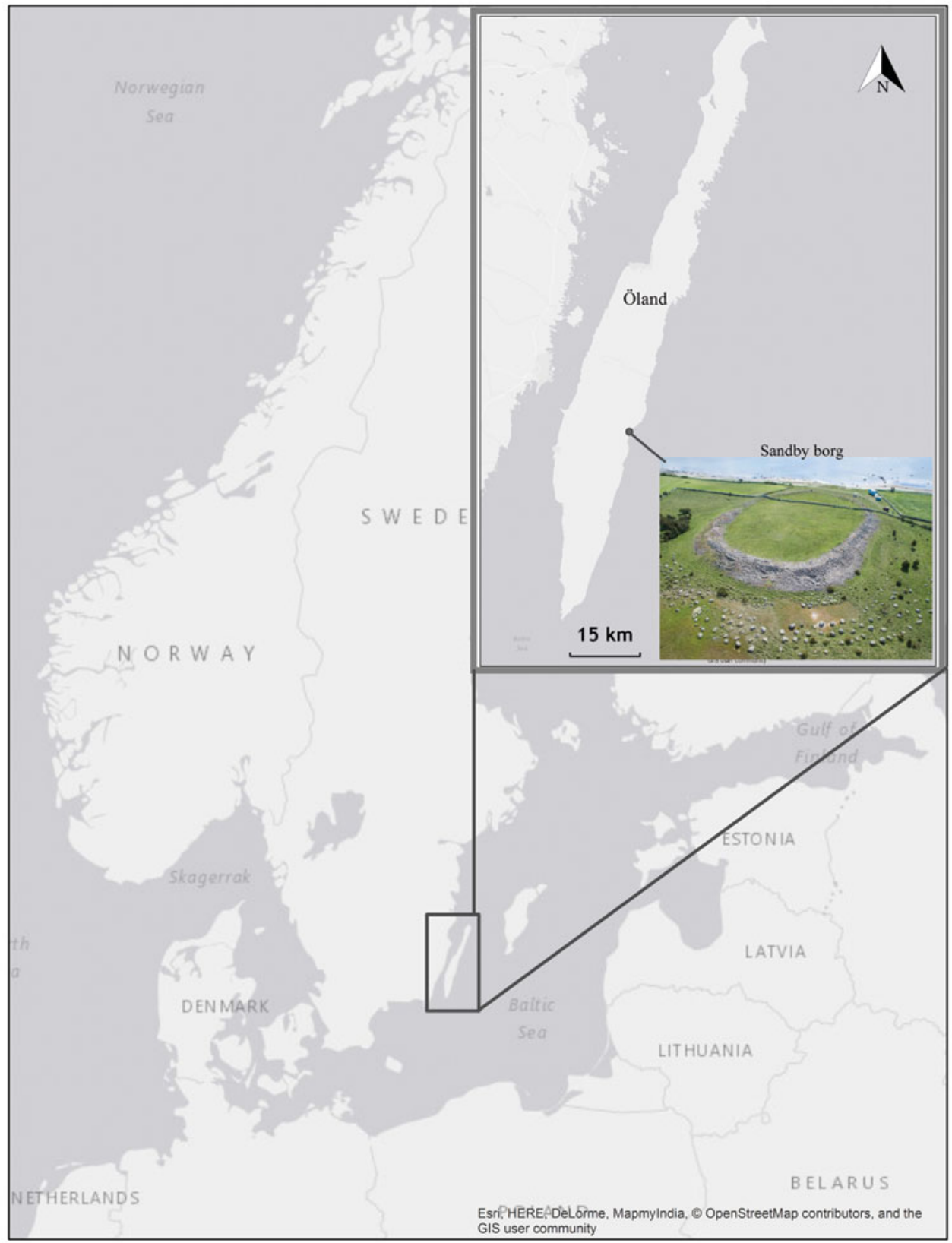

Figure 1. Map of Scandinavia with the island of Öland indicated. Inset is a map of Öland with the location of Sandby borg. Photograph: Sebastian Jakobsson. 


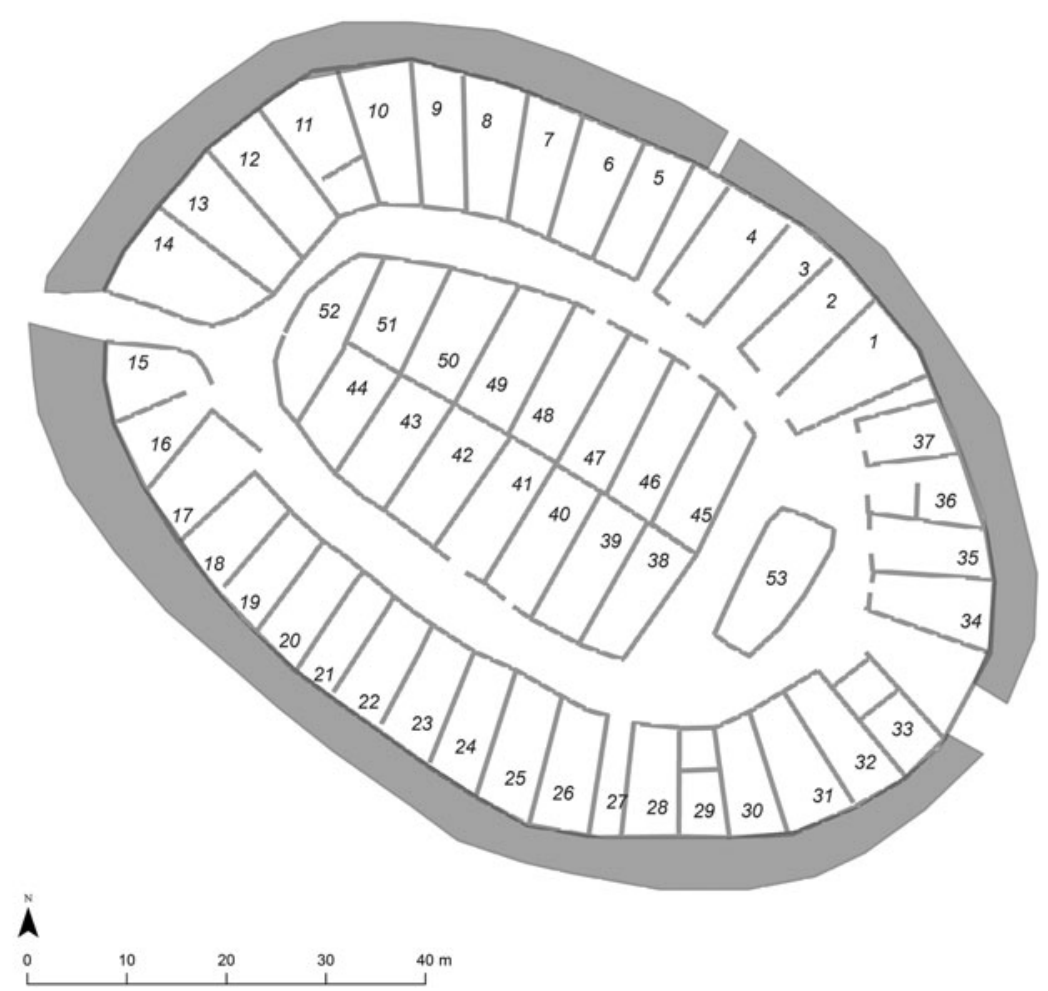

Figure 2. Plan of Sandby borg with the identified houses numbered. The overview is based on geophysical surveys (Viberg 2012), excavations and aerial photographs.

other Öland ringforts, with houses radially placed inside the ring wall and a central block surrounded by a street (Stenberger 1933; Borg et al. 1976) (Figures 2 \& 3).

Suspected looting pits were discovered during initial geophysical work in 2010. This led the local authorities to commission a metal-detector survey of the whole site. Five deposits of exquisite Migration Period jewellery were discovered hidden in different houses within the central block of the fort. Each deposit contained a gilded silver relief brooch (Figure 4) along with various items, such as glass beads, finger rings and silver pendants (Figure 5) (Blohmé et al. 2011; Victor 2015a; Fallgren \& Ljungkvist 2016). The relief brooches are large, prestigious items of a very high quality, typically made of gilded silver and covered with decorative animal art designs. The brooches, which were probably part of aristocratic women's jewellery sets, are decorated in Salins Style I and spiral ornamentations. Typologically, they can be dated to the period AD 450-510 (e.g. Haseloff 1981; Näsman 1984b; Magnus 1997, 2002; Kristoffersen 1999; Fischer \& Victor 2011). While the brooches were probably locally made, other artefacts in the deposits, such as millefiori glass beads, silver bell pendants and cowrie shell ornaments, are of non-local origin (Grabarczyk 1983; Näsman 1984b; Tempelmann-Mączynśka 1985; Sjøvold 1993; Volkmann \& Theune 2001; Tvauri 2012; Victor 2015a). The artefacts indicate contacts to the south-east, through present-day Poland, the Baltic states and into areas of the Roman Empire (see (C) Antiquity Publications Ltd, 2018 


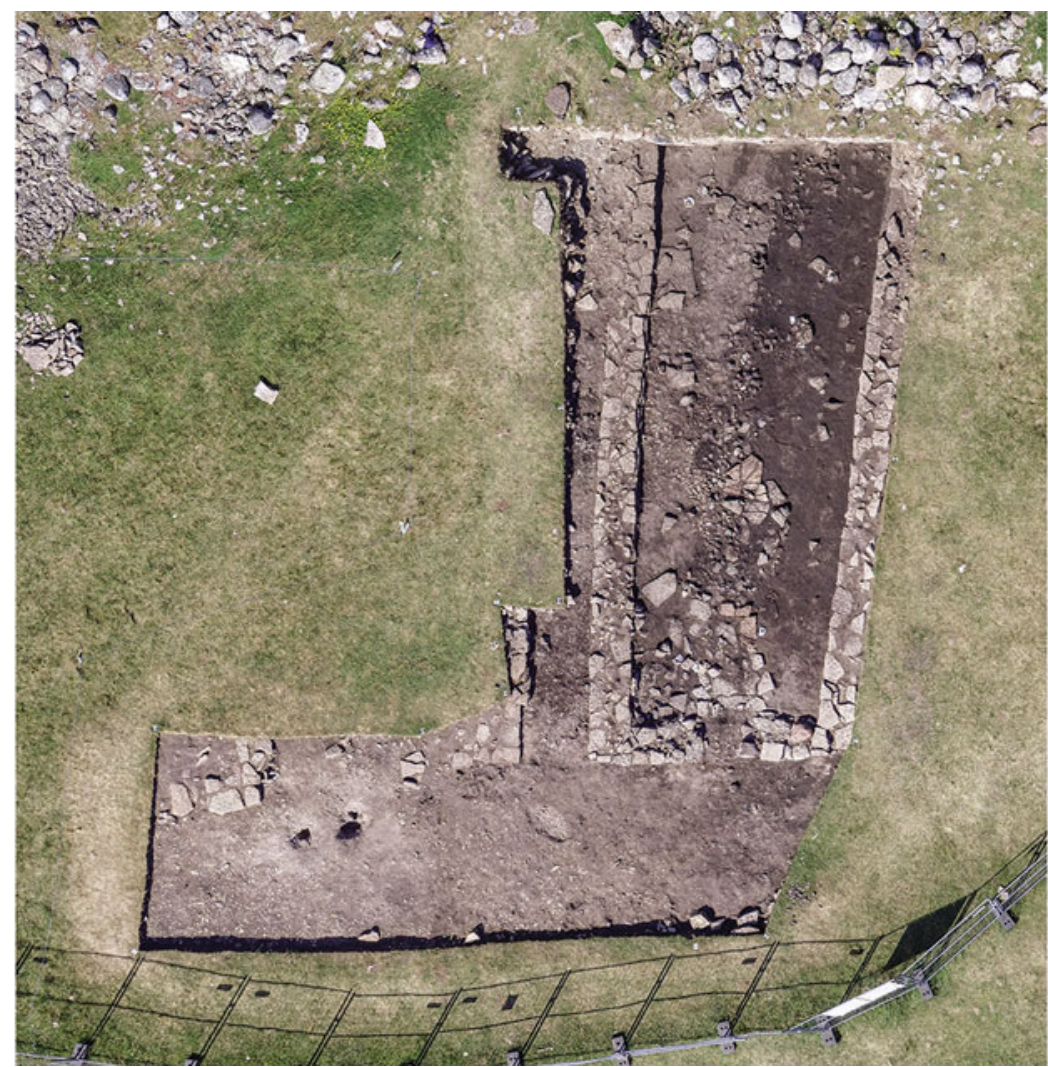

Figure 3. Aerial photograph of house 4 being excavated in 2016. The rectangular house foundation measures approximately $14 \times 6 \mathrm{~m}$. The eroded fort wall also constitutes the north-east wall of the house, as seen in the top of the photograph. Photograph: Sebastian Jakobsson.

Victor 2015a). Artefact typology suggests that the fort was in use during the Migration Period, with a focus on the later part of the fifth century AD.

\section{The excavations}

Small-scale annual excavations at Sandby borg have been undertaken by Kalmar County Museum since 2011. Initially, the aim was to establish the contexts of the deposits first discovered in 2010. During the first year of excavation, the discovery of human remains inside houses alerted the archaeologists that a violent event had occurred at the site in the late fifth century $\mathrm{AD}$.

By the end of the 2016 field season, approximately $300 \mathrm{~m}^{2}$ had been excavatedequivalent to six per cent of the total ringfort surface area (Dutra Leivas \& Victor 2011; Victor 2012, 2015b; Victor et al. 2013; Gunnarsson et al. 2016; PapmehlDufay \& Alfsdotter 2016). This includes the complete excavation of 2 of the 53 houses, approximately 50 per cent of a third house, and 6 houses subjected to limited investigation. Articulated human remains have been found in four of the houses, and

(C) Antiquity Publications Ltd, 2018 

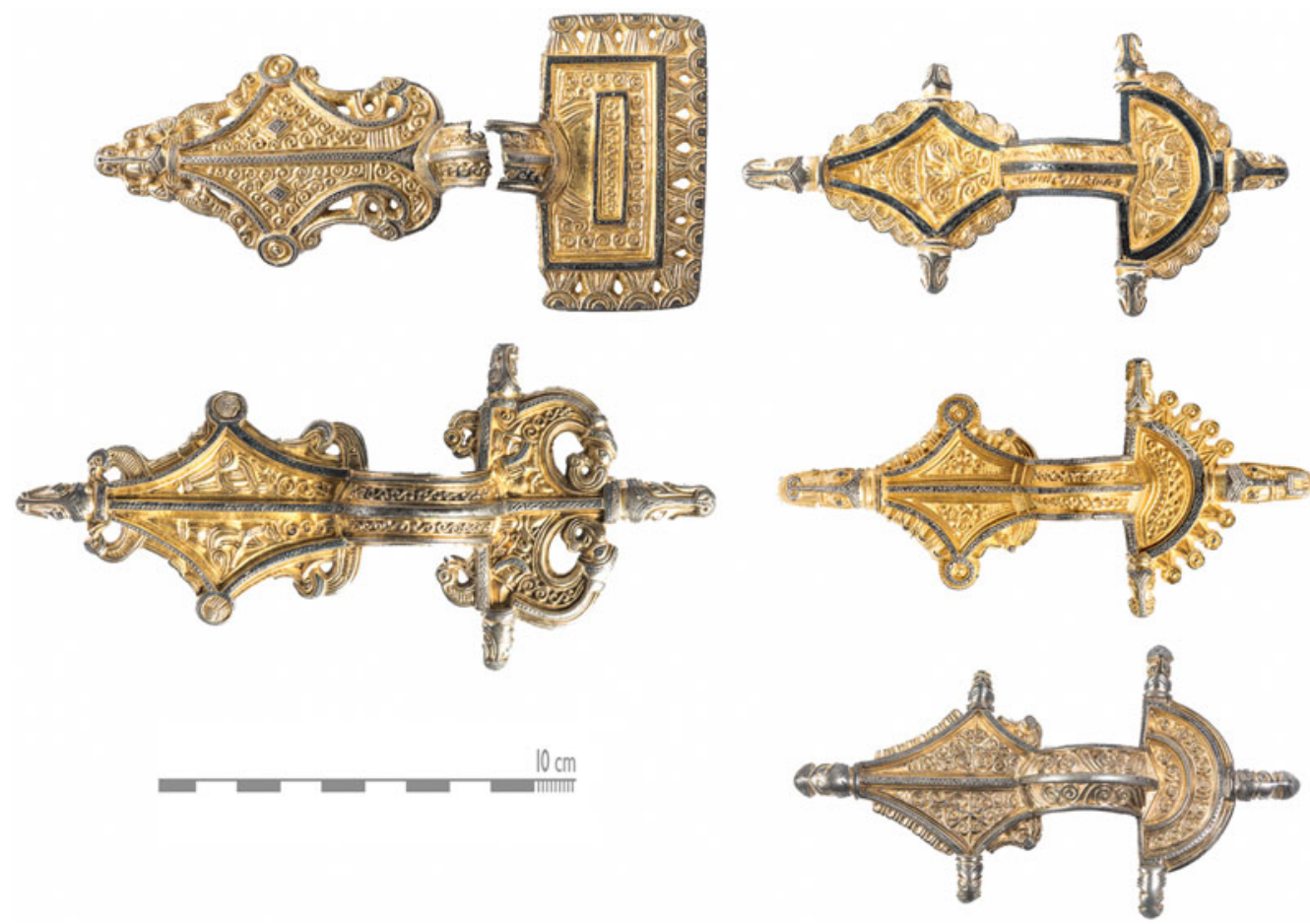

Figure 4. The five gilded relief brooches in silver found in five different deposits in 2010. Photograph: Daniel Lindskog.

scattered and commingled human remains found in the street surrounding the central block.

Ceramics were recovered in all of the excavated houses, in many cases in the form of fragmented but complete vessels. The entire site has been surveyed with metal detectors on several occasions, resulting in the recovery of bronze, silver, gold and some iron objects. Artefacts from the excavations include glass and silver beads, a gilded silver sword pendant, a large millefiori glass bead, a Valentinian III solidus (AD 425-455), yet another fragmented relief brooch and several other outstanding finds (Figure 6). Military equipment is limited to a handful of arrowheads, one lance-head and two or three unique sword details (Victor et al. 2013; Victor 2015b). Dating of the massacre to the late fifth century is based mainly on typological evidence (Victor 2015a). A current aim for the project is a major programme of ${ }^{14} \mathrm{C}$-dating, in which human and animal remains, as well as archaeobotanical material, will be dated. This will provide a solid base for understanding the chronology of the site.

\section{Defining a massacre}

The term 'massacre' has several definitions, some with well-defined social or quantitative implications, and others more general in character. In modern times, massacres are typically connected to contexts of war, and the killing is often preceded by cruel acts of violence and abuse (Dutton et al. 2005). In a study of the 1994 Rwanda genocide, massacre was defined as an event involving the killing of at least 100 people in a specific location in less

(C) Antiquity Publications Ltd, 2018 

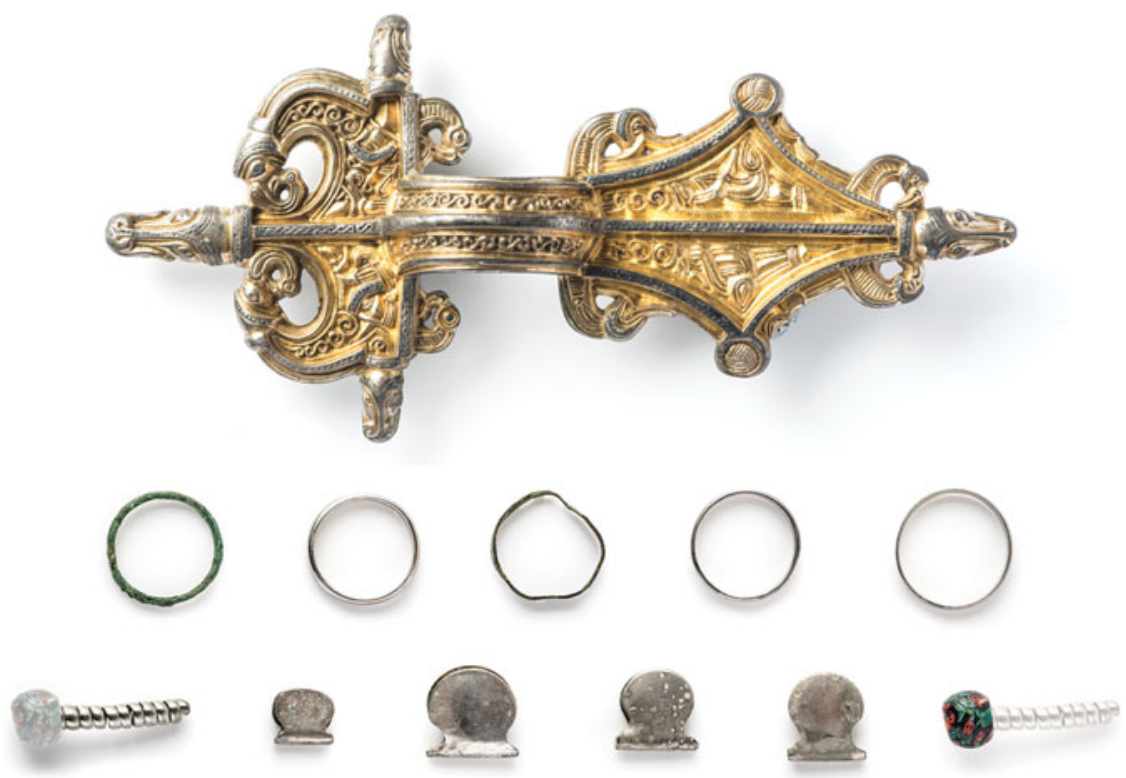

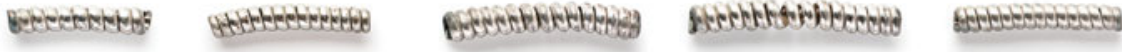

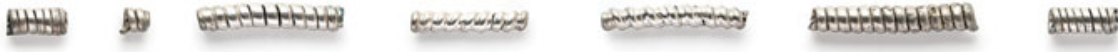
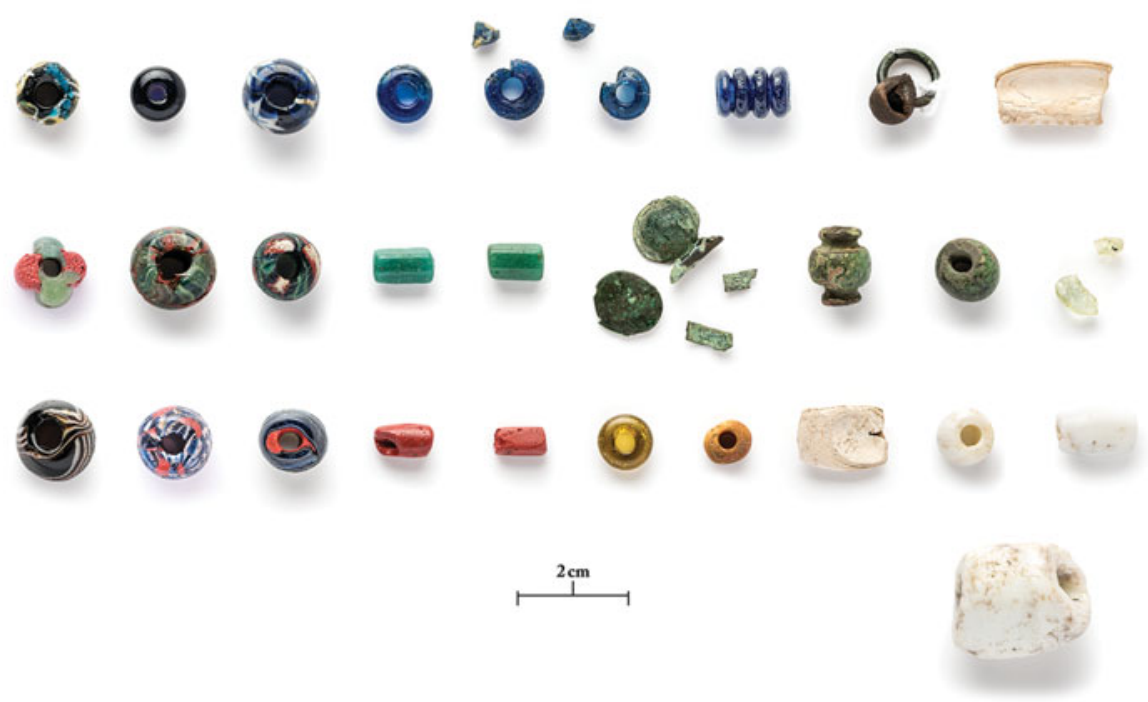

Figure 5. Objects found in deposit 2 (house 40), one of the five jewellery deposits encountered at Sandby borg during a metal detector survey in 2010. Photograph: Daniel Lindskog. 

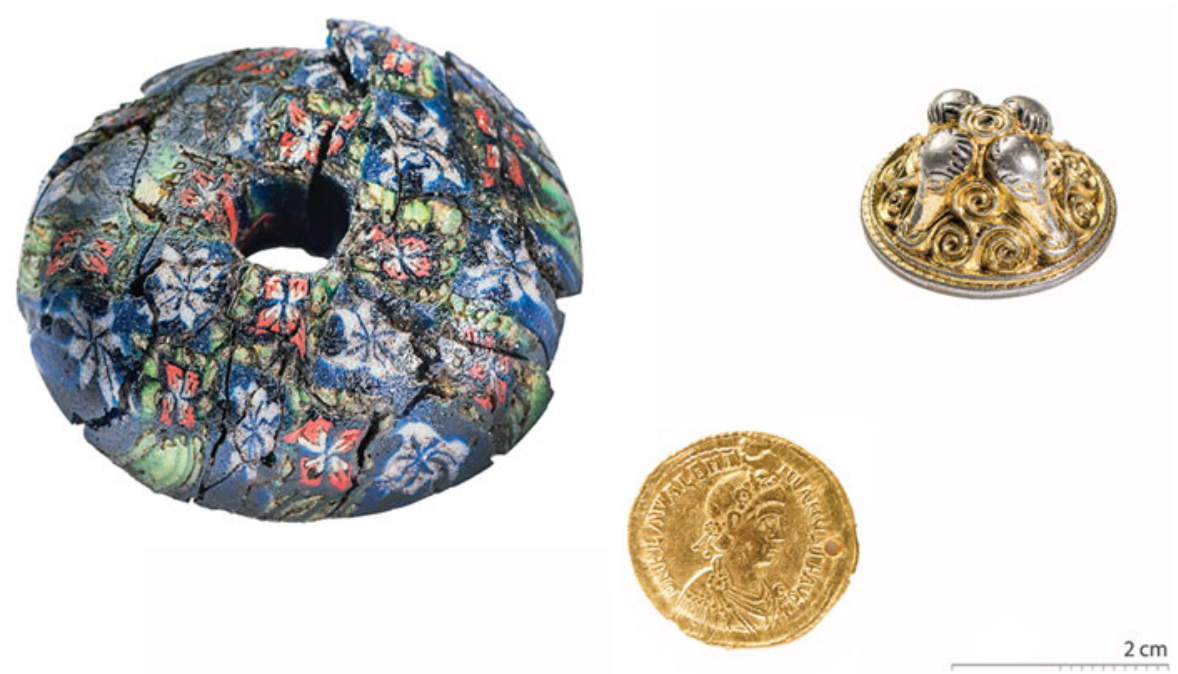

Figure 6. A large millefiori glass sword bead, a Valentinian III solidus and a gilded silver sword pendant found on the floor of house 40. Photograph: Daniel Lindskog.

than 3 days (Verwimp 2006: 12). In a study focusing on the rationality of mass killing in civil war contexts in Algeria, massacre was defined as involving large-scale, face-to-face violence against civilians targeted in groups. Massacres were systematically used as a strategy for punishing and deterring civilian resistance (Kalyvas 1999: 246). Here, we use the word 'massacre' as referring to an act of intentional murder upon a mass of people who were not prepared for battle, with the killing being conducted by a group.

\section{Body positions, spatial context and trauma}

To date, the remains of a minimum of 26 human individuals have been found at Sandby borg (bioarchaeological interpretations provided by Alfsdotter, unless otherwise specified). The context of the skeletal remains is unusual. Animal and human skeletons were found articulated and disarticulated on the floors of houses and on the streets. At least nine human individuals were found in house 40 (Figure 7), which has been fully excavated. Three of these have been sexed as males, and another two display secondary masculine morphological traits. Six of the skeletons were articulated, and skeletal elements of at least another three individuals were found in a disarticulated state. There are no indications that the disarticulated skeletons were deliberately dismembered. Rather, the disarticulation of the remains is interpreted as resulting from post-mortem taphonomic processes (for a taphonomic interpretation of the human remains in Sandby borg, see Alfsdotter \& Kjellström forthcoming). Among the disarticulated elements are three vertebrae of a young child aged approximately $2-5$ years, and the femur of a $1.5-3$-month-old infant.

Perimortal interpersonal trauma has been identified on the skulls of at least four adults from house 40. The skull of one young adolescent displays signs of blunt-force perimortem trauma. Of the six articulated individuals, three were in extended positions (both prone and supine), indicating sudden death or unconsciousness before death. Two individuals (C) Antiquity Publications Ltd, 2018 


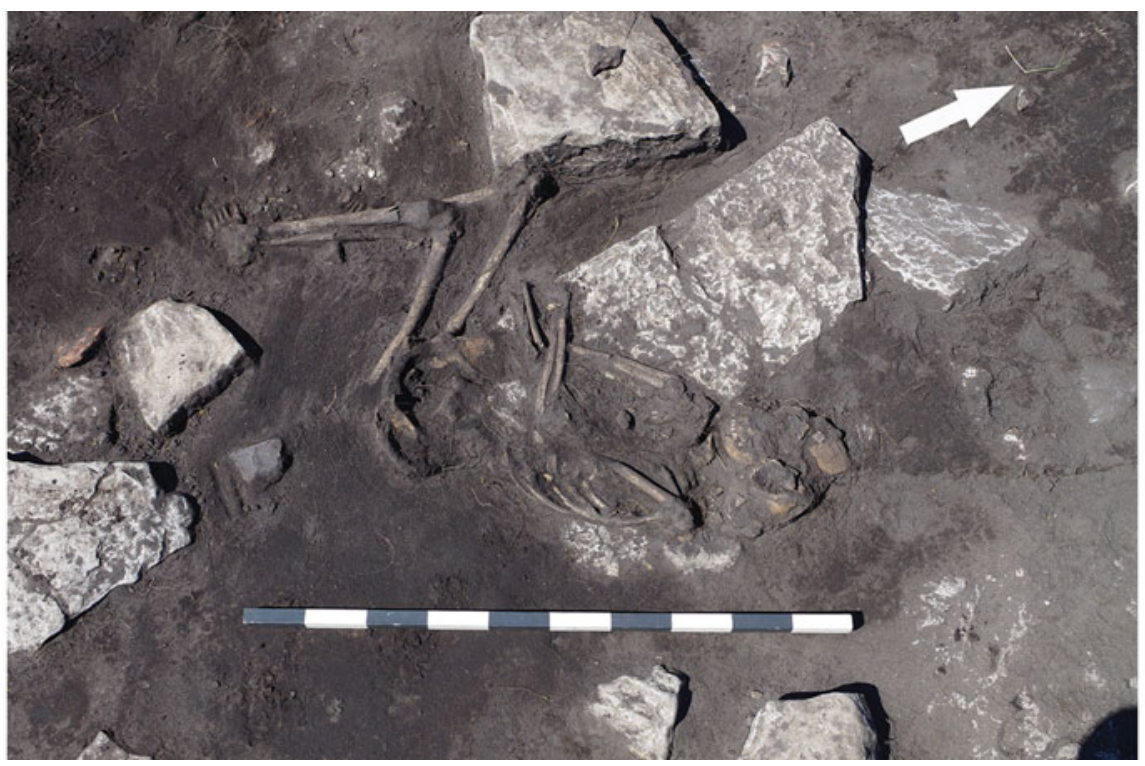

Figure 7. One of the nine human skeletons found on the floor level of house 40. This adolescent was found lying on their side. The white arrow points north. Photograph: Kalmar County Museum.

had extended upper bodies with slightly flexed legs, and one adolescent was found lying on their side (Figure 8). The adolescent may have experienced a slower death, allowing him or her to flex. There is no evidence suggesting that the individuals were placed or moved after death (Alfsdotter \& Kjellström forthcoming). One of the adolescents lay flat on their back, with their feet over the pelvis of an adult, suggesting that the adult was already lying motionless on the floor when the adolescent fell backwards over him.

Two of the human skeletons in house 40 were partially charred and disarticulated. The character of the thermal trauma suggests that fire consumed the bodies before the soft tissue had decomposed (Alfsdotter \& Kjellström forthcoming). This suggests that raiders attempted to set some houses on fire, or that a fire broke out by accident. That the fire eventually extinguished itself before any bodies were completely charred is supported by the presence of charred logs inside the houses, and archaeobotanical samples containing charred roots and herb stems - presumably the remains of turf roofs (Gunnarsson et al. 2016; Heimdahl 2016). The majority of the excavated houses and their contents, however, were untouched by fire.

Disarticulated human and animal remains have been found in other houses and on the street surrounding the central block. In front of one of the houses, the partially articulated remains of a horse were discovered (Victor 2015b). Several articulated dog and sheep skeletons were found inside the houses, suggesting that animals were left to starve or, in some cases, may have been killed during the attack (animal scavenging is discussed in Alfsdotter \& Kjellström forthcoming). There are also remains stored in houses from animals that had been slaughtered and dismembered prior to the attack but not yet consumed. Archaeozoological analysis of the faunal assemblage is ongoing.

(C) Antiquity Publications Ltd, 2018 


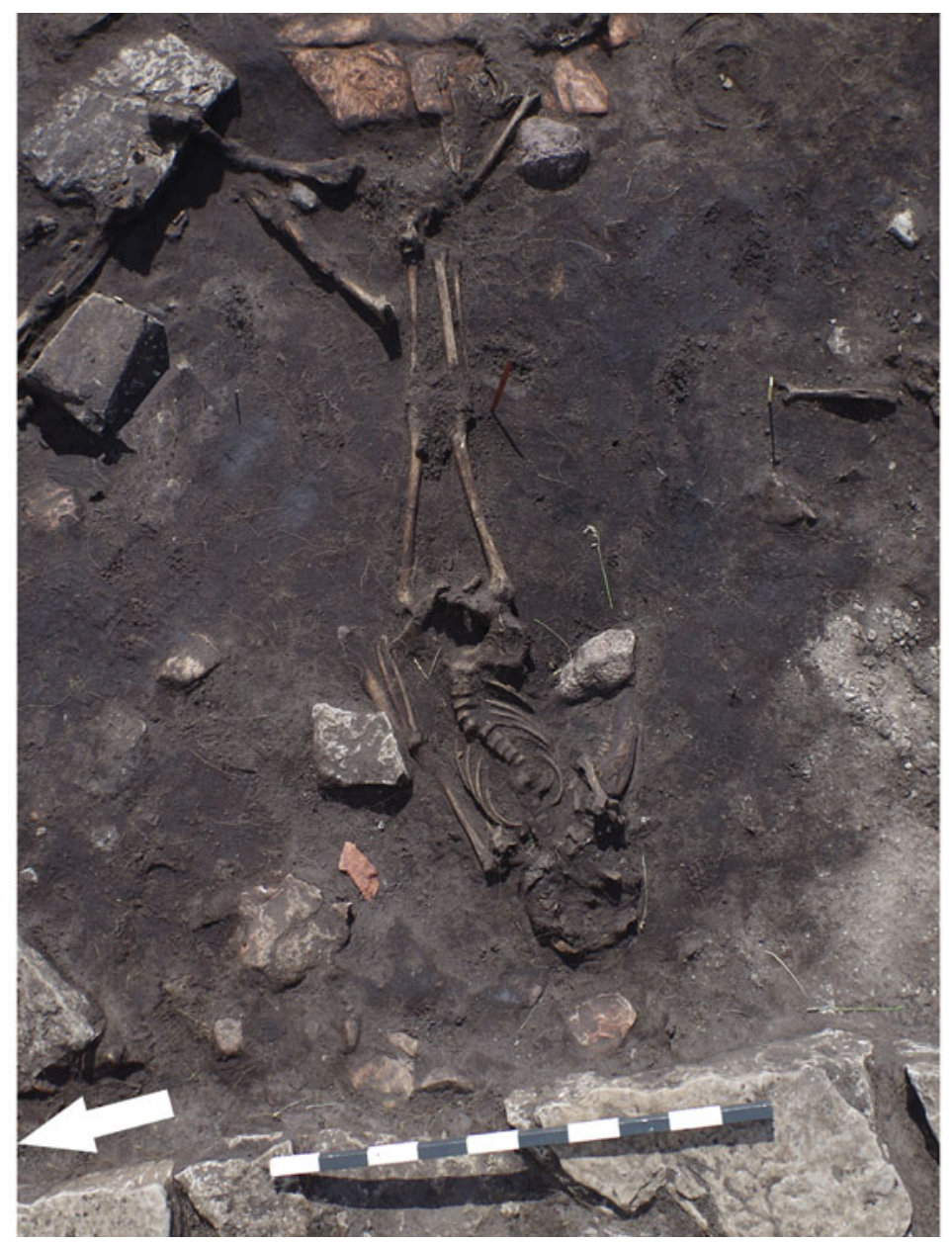

Figure 8. The skeletal remains of two individuals inside house 40. The remains of the young teenager are stretched out, with the feet on top of the pelvis of an adult man, suggesting that the teenager fell backwards over the dead or dying adult. The adolescent (12-15 years old) displays perimortem blunt force on the skull (Gunnarsson et al. 2016). The western house wall is at the bottom of the picture. The white arrow points north. Photograph: Kalmar County Museum.

In house 52, which has only been partially excavated, the skeleton of an elderly man was found lying face down across the central hearth (Papmehl-Dufay \& Alfsdotter 2016). Parts of the pelvis area were burnt, the extent of charring indicating that soft tissue was present when his body fell across the hearth. He was lying stretched out, with legs crossed and arms straight. His head was mostly absent due to taphonomic disturbance, apart from the lower jaw and some skull fragments. The body position and charring suggests that he fell face down over the still burning hearth, and that he was dead or unconscious when he fell.

The trauma evident on several skulls, on one man's shoulder and one man's hip resulted from blows aimed at the back or the side of the bodies. Perimortem damage resembling common battle injuries, such as parry fractures or facial trauma (Roberts \& Manchester 2007: 108-109), both typically produced when facing an opponent-has so far not been (C) Antiquity Publications Ltd, 2018 
identified. This pattern leads us to conclude that the perpetrators comprised a large number of people, striking simultaneously in several houses, and that several of the victims were not in a position to defend themselves.

\section{Demography of the massacred}

Demographic observations can be made concerning the recovered individuals (at least 26 in number). All age groups are represented, from infants and young children to older adults. So far, none of the osteologically sexed skeletons display female morphological traits. Several of the skeletons, however, are those of sub-adults that cannot be sexed osteologically, and the poor preservation of some of the skeletons precluded sex determination.

\section{The season of the massacre}

The skeletons of eight lambs were found piled adjacent to a wall inside house 40 . Osteological analysis reveals that the lambs were recently slaughtered and partially dismembered. The assemblage was probably stored in a now decomposed container. The lambs were all of similar age at the time of death, approximately 3-6 months old. As lambs are traditionally born during spring, the presence of newly slaughtered but uneaten lambs suggests that the assault was conducted sometime between late spring and early autumn (Gunnarsson et al. 2016).

\section{A moment frozen in time}

The fact that articulated human and animal skeletons were found at the site shows that the ringfort was abandoned after the massacre. We encountered skeletons on the floors of the houses and on the surface of the streets, indicating the original ground surface (in the cases where the bodies had not originally fallen on top of furniture or similar). The articulated condition of several skeletons inside the houses - in some cases just inside the entrancebears witness to the cessation of human activity after the assault. In houses where the roof turf did not collapse as a result of fire, the bodies would have been left to decompose unburied where they lay, until the houses eventually caved in (Alfsdotter \& Kjellström forthcoming).

The extent of skeletal articulation as an indicator that the ringfort was left undisturbed is illustrated by a particular find in house 40. Adjacent to the fireplace, the articulated skeleton of half a herring was found (Victor 2015b). The fact that the fragile and edible fish was left intact strongly suggests that human activity inside the house ceased immediately following the massacre. The large quantity of artefacts encountered on the original floor-level inside the houses strengthens the theory that the fort was not reused. In the southern part of house 40, for example, numerous glass and silver beads and half a relief brooch were found scattered over the floor.

\section{Discussion}

The archaeological context of Sandby borg is unusual in several respects. The human remains provide a snapshot of Migration Period violence with a level of detail rarely seen. 
The site also offers a rare opportunity to study aspects of everyday life of a Migration Period ringfort. Several observations strongly indicate that the entire site was abandoned suddenly, resulting in a detailed set of data concerning domestic life.

In many ways, the archaeology of Sandby borg relates to the archaeology and bioarchaeology of battlefields, mass graves and violence (e.g. Martin \& Frayer 1997; Scott et al. 1998; Knüsel \& Smith 2014; Loe et al. 2014). The contextual circumstances at Sandby borg, however, still make it unique in the archaeological record. In most cases where human remains have been found in connection with battlefields or scenes of brutal violence, the bodies have been buried in mass graves (e.g. Ingelmark 1939; Biers 1992; Fiorato et al. 2000; Kjellström 2005; Štefan et al. 2016). This is not the case at Sandby borg, where victims were instead left where they had been killed.

A lack of osteological evidence for females among the dead suggests that the massacre at Sandby borg may have been gender-biased towards the male inhabitants. This theory is weakened, however, by the relatively small area of the site excavated to date, and may be refuted through further excavation and analysis. The discovery of infant bones reveals that women were present at the site, although not necessarily at the time of the attack. The demographic composition of the victims at Sandby borg includes people of all ages, which is peculiar; the victims of battlefield violence usually represent particular segments of a population-people who have actively participated in acts of warfare (e.g. Štefan et al. 2016).

The fact that many of the individuals were left unburied inside the ringfort indicates that nobody came back to tend the dead. Several scenarios are possible: all the inhabitants may have been killed; some may have been killed and others abducted; or some may have fled but were unable or unwilling to return. The evidence suggests that no survivors or neighbours could, or wanted to, enter the site after the massacre. The event most probably had a major long-term impact on surrounding settlements and inhabitants. Unlike many of the ringforts on the island of Öland (cf. Borg et al. 1976; Näsman \& Wegraeus 1979), Sandby borg shows no signs of reuse after the Migration Period. In that respect it appears to be unique, although due to limited excavation, we cannot rule out the possibility that similar attacks were conducted at other ringforts.

The bioarchaeological material offers large quantities of data rarely encountered from this period and area. Besides details regarding the violent attack, the deaths of the victims and clues about spatial and architectural details, the human remains also provide vital knowledge concerning the victims' lives and general health. Inhumations from the Scandinavian Migration Period are rare, as cremation was the dominant burial custom (Bennett 1987; Hagberg \& Beskow-Sjöberg 1996). In this context, the Sandby borg human remains constitute an important source of data for analysis of stable isotopes, ancient DNA and bioarchaeology.

The evidence for interpersonal violence at Sandby borg contrasts with the almost total lack of weapons and military equipment. Finds of this type are limited to a couple of sword fittings, a small chape, a sword pendant, a lance head and a few arrowheads. Weapons such as swords, spears and shields were probably kept and used in large quantities at a site such as Sandby borg. This assumption is based mainly on the widespread occurrence of weapons in contemporaneous graves, the undisputed position of warrior ideology in Migration Period (C) Antiquity Publications Ltd, 2018 
Scandinavia and the presumed military character of the site in general (Fabech 1991; Rasch 1991; Näsman 1997; Olausson 2000; Fischer 2005; Hedeager 2011). The sparseness of evidence for weapons in the excavated and metal-detector-surveyed material could mean that they were removed from the scene following the massacre. While the motives for such an act can only be speculated upon, the widespread custom of depositing military equipment in lakes or marshes during the preceding Roman Iron Age (e.g. at Nydam and Illerup in Denmark, and at least two such deposits on Öland) could offer an explanation (Fabech 1991). At the sacrificial bog of Skedemosse on Öland, six different deposits of weapons and military equipment have been identified, two of them dated to the Migration Period (Hagberg 1967; Rau 2005; Monikander 2010). These deposits include numerous swords, shield bosses, sword chapes, sword beads (decorative attachments on swords and scabbards, often made of glass; see Figure 6) and other sword details, and combs. While it is not possible to connect the bog directly to Sandby borg, the Skedemosse site does show that the custom of depositing military equipment in sacrificial bogs was practised on Öland at the time of the massacre.

The suggested date of the Sandby borg massacre corresponds to the period after the fall of the Western Roman Empire in $\mathrm{AD} 476$, an event that had a significant impact on large parts of Europe, including southern Scandinavia (Lund Hansen 1987; Fischer 2005; Heather 2006; Hedeager 2011). The assault on Sandby borg may have been the result of subsequent power struggles on the island, at a time when the political map and power structures were being rewritten across the European continent. Considerable quantities of important trade goods (e.g. wealth items and live animals) were destroyed or abandoned at the site. The massacre at Sandby borg cannot, therefore, be explained simply as an act of outright plunder. One possible scenario is that the perpetrators at Sandby borg established themselves as the new local ruling elite.

\section{Conclusions}

Combining osteological evidence of trauma with the archaeological context and the taphonomy of the skeletons has been crucial to our interpretations. We argue that a massacre was carried out at Sandby borg — probably at the end of the fifth century AD—and that the ringfort was abandoned immediately following this event. The dead individuals span all age groups but are gender-biased towards males. The site provides a snapshot of the moment of both the massacre and everyday life that was halted brutally. We do not interpret the massacre as an act of outright plunder, but rather as one that was connected to political instability during the turbulent Migration Period.

\section{References}

Alfsdotter, C. \& A. KJellström. Forthcoming. A taphonomic interpretation of the postmortem context following the mass killing at Sandby borg.

Andrén, A. 2014. Tracing Old Norse cosmology: the world tree, middle earth, and the sun in archaeological perspectives (Vägar till Midgård 16). Lund: Nordic Academic.
BennetT, A. 1987. Graven-religiös och social symbol: strukturer i folkvandringstidens gravskick $i$ Mälardalen. Stockholm: Stockholms universitet.

Biers, W. 1992. Art, artefacts and chronology in classical archaeology. London: Routledge.

(C) Antiquity Publications Ltd, 2018 
Blohmé, M., J.-H. Fallgren \& Y. Bäckström. 2011. Sandby borg på Öland. Fem depåfynd av praktspännen från folkvandringstid. Efterundersökning av plundringsgropar. Sandby borg, Sandby socken, fornlämning nr 45:1, Mörbylånga kommun, Öland, Kalmar län. Unpublished report.

Borg, K., U. Näsman \& E. Wegraneus (ed.). 1976. Eketorp. Fortification and settlement on Öland/Sweden. The monument. Stockholm: Royal Academy of Letters, History and Antiquities.

Dutra Leivas, I. \& H. Victor. 2011. Sandby borg I. Undersökningar 2011. Sandby socken, Mörbylånga kommun, Öland (Sandby borgs skrifter 1). Kalmar: Kalmar läns museum.

Dutton, D.G., E.O. Boyanowsky \& M. Harris Bond. 2005. Extreme mass homicide: from military massacre to genocide. Aggression and Violent Behaviour 10: 437-73. https://doi.org/10.1016/j.avb.2004.06.002

FABECH, C. 1991. Samfundsorganisation, religiøse ceremonier og regional variation. Offerfund som kilde til jernalderens samfundsforhold, in C. Fabech \& J. Ringtved (ed.) Samfundsorganisation og Regional Variation (Jysk Arkæologisk Selskabs Skrifter XXVII): 283-303. Aarhus: Aarhus University Press.

FAGERLIE, J.M. 1967. Late Roman and Byzantine solidi found in Sweden and Denmark (Numismatic Notes and Monographs 157). New York: American Numismatic Society.

FAllgren, J.-H. 2006. Kontinuitet och förändring. Bebyggelse och samhälle på Öland 200-1300 e. Kr. (Aun 35). Uppsala: Department of Archaeology and Ancient History, Uppsala University.

- 2008. Fornborgar, bebyggelse och odlingslandskap, in G. Tegnér (ed.) Gråborg på Öland. En borg, ett kapell och en by: 119-36. Stockholm: Royal Academy of Letters, History and Antiquities.

FAllgren, J.-H. \& J. Ljungkvist. 2016. The ritual use of brooches in early medieval forts on Ö̈and, Sweden. European Journal of Archaeology 19: 4.

Fiorato, V., A. Boylston \& C. Knüsel. 2000. Blood red roses: the archaeology of a mass grave from the Battle of Towton AD 1461. Oxford: Oxbow.

Fischer, S. 2005. Roman imperialism and runic literacy: the westernization of Northern Europe (150-800 AD) (Aun 33). Uppsala: Department of Archaeology and Ancient History, Uppsala University.

Fischer, S. \& H. Victor. 2011. New horizons for Helgö. Recent research on the East Scandinavian Migration Period, in B. Arrhenius \& U. O'Meadhra (ed.) Excavations at Helgö XVIII: conclusions and new aspects: 79-92. Stockholm: Kungl. Vitterhetsakademien.
Fischer, S., F. Lopez Sanchez \& H. Victor. 2011. The $5^{\text {th }}$-century hoard of Theodosian solidi from Stora Brunneby, Öland, Sweden. A result from the LEO project. Fornvännen 106: 189-204.

GrabarczyK, T. 1983. Metalowe rzemiosto artystyczne na Pomorzu w okreise rzymskim (Nauk Społecznych i Humanistycznych 9). Wrocław: Zakład Narodowy im. Ossolińskich.

Gunnarsson, F., H. Victor \& C. Alfsdotter. 2016. Sandby borg VII. Undersökningar 2015. Sandby socken, Mörbylånga kommun, Öland (Sandby borgs skrifter 7). Kalmar: Kalmar läns museum.

Hagberg, U.E. 1967. The archaeology of Skedemosse I. The excavation and the finds of an Öland fen, Sweden (Monographs 46). Stockholm: Royal Academy of Letters, History and Antiquities.

Hagberg, U.E. \& M. Beskow-SJöвerg. 1996. Ölands järnåldersgravfält (volume III). Stockholm: Riksantikvarieämbetet och Statens historiska museer.

Haseloff, G. 1981. Die germanische Tierornamentik der Völkerwanderungszeit: Studien zu Salin's Stil I (Vorgeschichtliche Forschungen 17). Berlin: De Gruyter. https://doi.org/10.1515/9783110884111

Heather, P.J. 2006. The fall of the Roman Empire: a new history of Rome and the barbarians. New York: Oxford University Press.

Hedeager, L. 2011. Iron Age myth and materiality: an archaeology of Scandinavia AD 400-1000. London: Routledge.

Heimdahl, J. 2016. Växtmakrofossilanalyser, in L. Papmehl-Dufay \& C. Alfsdotter (ed.) Sandby borg V. Seminariegräuning 2014. Sandby socken, Mörbylanga kommun, Öland (Sandby borgs skrifter 5) Kalmar: Kalmar läns museum.

Herschend, F. 1980. Två studier i öländska guldfynd. 2. Det omyntade guldet (Tor 18). Uppsala: Gustavianum.

- 1991. Om öländsk metallekonomi i första hälften av första årtusendet e. Kr., in C. Fabech \& J. Ringtved (ed.) Samfundsorganisation og Regional Variation. Norden i Romersk Jernalder og Folkevandringstid: 33-46. Aarhus: Aarhus University Press.

INGELMARK, B.E. 1939. The skeletons, in B. Thordeman (ed.) Armour from the Battle of Wisby 1361: 149-209. Stockholm: Royal Academy of Letters, History and Antiquities.

JørGENSEN, L. 2003. Kosmopolitiske aristokrater, in L. Jørgensen, B. Storgaard \& L. Gebauer Thomsen (ed.) Sejrens triumf, Norden i skyggen af det romerske imperium: 106-25. København: Nationalmuseet. 
- 2011. Gudme-Lundeborg on Funen as a model for Northern Europe?, in O. Grimm \& A. Pesch (ed.) The Gudme/Gudhem phenomenon: papers presented at a workshop organized by the Centre for Baltic and Scandinavian Archaeology (ZBSA), Schleswig, April $26^{\text {th }}$ and 27th 2010 (Schriften des Archäologischen Landesmuseums Ergänzungsreihe Band 6): 77-89. Neumünster: Wachholtz.

Kalyvas, S.N. 1999. Wanton and senseless? The logic of massacres in Algeria. Rationality and Society 11: 243-85. https://doi.org/10.1177/104346399011003001

KJellström, A. 2005. A sixteenth-century warrior grave from Uppsala, Sweden: the Battle of Good Friday. International Journal of Osteoarchaeology 15: 23-50. https://doi.org/10.1002/oa.746

Knüsel, C. \& M.J. Sмith (ed.). 2014. The Routledge handbook of the bioarchaeology of human conflict. London \& New York: Routledge.

Kristoffersen, S. 1999. Migration Period chronology in Norway, in J. Hines, K. Højlund Nielsen \& F. Siegmund (ed.) The pace of change: studies in early medieval chronology: 93-114. Oxford: Oxbow.

Loe, L., A. Boyle, H. Webb \& D. Score. 2014. 'Given to the ground': a Viking Age mass grave on Ridgeway Hill, Weymouth (Dorset Natural History \& Archaeological Society Monograph Series 22). Dorchester: Dorset Natural History \& Archaeological Society.

Lund Hansen, U. 1987. Römischer Import im Norden. Warenaustausch zwischen dem Römischen Reich und dem freien Germanien während der Kaiserzeit unter besonderer Berücksichtigung Nordeuropas (Nordiske fortidsminder, Serie B in quarto 10). Kopenhagen: Kongelige Nordiske Oldskriftselskab.

Magnus, B. 1997. The firebed of the serpent: myth and religion in the Migration Period mirrored through some golden objects, in L. Webster \& M.P. Brown (ed.) The transformation of the Roman world $A D$ 400-900: 194-207. London: British Museum.

- 2002. Ørnen flyr - om Stil I i Norden. Hikuin 29: 105-18.

Martin, D.L. \& D.W. Frayer (ed.). 1997. Troubled times: violence and warfare in the past. Amsterdam: Gordon \& Breach.

Monikander, A. 2010. Våld och vatten. Våtmarkskult vid Skedemosse under järnåldern (Stockholm Studies in Archaeology 52). Stockholm: Stockholm University.

NäSMAN, U. 1984a. Glas och handel i senromersk tid och folkvandringstid: en studie kring glas frain Eketorp-II, Öland, Sverige (Aun 5). Uppsala: Department of Archaeology and Ancient History, Uppsala University.
- 1984b. Zwei Relieffibeln von der Insel Öland. Praehistorische Zeitschrift 59(1): 48-80.

- 1988. Den folkvandringstida krisen i Sydskandinavien, inklusive Öland och Gotland, in U. Näsman \& J. Lund (ed.) Folkevandringstiden $i$ Norden: en krisetid mellem aldre og yngre jernalder: rapport fra et bebyggelsearkaologisk forskersymposium i Degerhamn, Öland, d. 2-4 oktober 1985: 227-55. Aarhus: Universitetsforlag.

- 1997. Strategies and tactics in Migration Period defence: on the art of defence on the basis of the settlement forts of Öland, in A. Nørgård Jørgensen \& B.L. Clausen (ed.) Military aspects of Scandinavian society in a European perspective, $A D$ 1-1300 (Publications from the National Museum 2): 146-55. Copenhagen: PNM.

Näsman, U. \& E. Wegraeus (ed.). 1979. Eketorp. Fortification and settlement on Öland/Sweden. The setting. Stockholm: Royal Academy of Letters, History and Antiquities.

Olausson, M. 2000. Husabyar, krig och krigare, in M. Olausson (ed.) En bok om Husbyar (Arkeologiska undersökningar, Skrifter 33): 125-50. Stockholm: Riksantikvarieämbetet.

Papmehl-Dufay, L. \& C. Alfsdotter. 2016. Sandby borg V. Seminariegrävning 2014. Sandby socken, Mörbylånga kommun, Öland (Sandby borgs skrifter 5). Kalmar: Kalmar läns museum.

Rasch, M. 1991. Kan gravseden spegla social och politisk utveckling? En närstudie av ett stort arkeologiskt material från en liten ö, in C. Fabech $\&$ J. Ringtved (ed.) Samfundsorganisation og Regional Variation. Norden i romersk jernalder og folkevandringstid (Jysk Arkæologisk Selskaps SKrifter XXVII): 133-39. Aarhus: Aarhus University Press.

RaU, A. 2005. Skedemosse. \$4. Kriegsbeuteopfer. Reallexikon der Germanischen Altertumskunde 28: 632-35.

Roberts, C. \& K. Manchester. 2007. The archaeology of disease (volume 3). New York: Cornell University Press.

Scott, D.D., P. Willey \& M.A. Connor. 1998. They died with Custer: soldiers' bones from the Battle of the Little Bighorn. Norman: University of Oklahoma Press.

Sృøvold, T. 1993. The Scandinavian relief brooches of the Migration Period (Norske Oldfunn XV). Oslo: Oldsaksamlingen.

ŠTefan, I., P. STRÁNSKÁ \& H. VondRovÁ. 2016. The archaeology of early medieval violence: the mass grave at Budeč, Czech Republic. Antiquity 90: 759-76. https://doi.org/10.15184/aqy.2016.29 


\section{Clara Alfsdotter et al.}

STENBerger, M. 1933. Öland under äldre järnåldern en bebyggelsehistorisk undersökning (Monographs 19). Uppsala: Royal Academy of Letters, History and Antiquities.

Tempelmann-Mączynśka, M. 1985. Die Perlen der römischen Kaiserzeit und der frühen Phase der Völkerwanderungszeit im mitteleuropäischen Barbaricum. Mainz am Rhein: Philipp von Zabern.

Tvauri, A. 2012. The Migration Period, pre-Viking Age, and Viking Age in Estonia (Estonian Archaeology 4). Tartu: Tartu University Press.

Verwimp, P. 2006. Machetes and firearms: the organizations of massacres in Rwanda. Journal of Peace Research 43: 5-22. https://doi.org/10.1177/0022343306059576

VIBERG, A. 2012. Remnant echoes of the past: archaeological geophysical prospection in Sweden (Theses and Papers in Scientific Archaeology 13). Stockholm: Stockholm University.

Viberg, A., H. Victor, S. Fischer, K. Lidèn \& A. Andreìn. 2014. The ringfort by the sea: archaeological geophysical prospection and excavations at Sandby borg (Öland). Archäologisches Korrespondenzblatt 44: 413-28.
VICTOR, H. 2012. Sandby borg II. Undersökningar 2012. Sandby socken, Mörbylånga kommun, Öland (Sandby borgs skrifter 2). Kalmar: Kalmar läns museum.

- 2015a. Sandby borg. Ett fruset ögonblick under folkvandringstiden, in K.-H. Arnell \& L. Papmehl-Dufay (ed.) Grävda minnen. Från Skedemosse till Sandby borg (Meddelanden från Kalmar läns hembygdsförbund och Stiftelsen Kalmar läns museum, årg. 95): 96-115. Kalmar: Kalmar läns museum.

- 2015b. Sandby borg IV. Undersökningar 2014. Sandby socken, Mörbylånga kommun, Öland (Sandby borgs skrifter 4). Kalmar: Kalmar läns museum.

Victor, H., A. Emilsson \& M. Frisk. 2013. Sandby borg III. Undersökningar 2013. Sandby socken, Mörbylånga kommun, Öland (Sandby borgs skrifter 3). Kalmar: Kalmar läns museum.

Volkmann, A. \& C. Theune. 2001. Merowingerzeitliche Millefioriperlen in Mitteleuropa. Ethnographisch-Archäologische Zeitschrift 42: 521-53.

Received: 31 March 2017; Accepted: 21 June 2017; Revised: 28 June 2017

(C) Antiquity Publications Ltd, 2018 